\title{
Phenotypic characterization of the marine pathogen Photobacterium damselae subsp. piscicida
}

\author{
A. Thyssen, L. Grisez, † R. van Houdt and F. Ollevier \\ Author for correspondence: A. Thyssen. Tel: +32163239 66. Fax: + 3216324575 . \\ e-mail: an.thyssen@student.kuleuven.ac.be
}

Laboratory of Ecology and Aquaculture, Zoological Institute, K. U. Leuven, Naamsestraat 59, B-3000 Leuven, Belgium

\begin{abstract}
The taxonomic position of Photobacterium damselae subsp. piscicida, the causative agent of fish pasteurellosis, is controversial as this organism has also been described as 'Pasteurella piscicida'. To clarify the taxonomic position of the pathogen, a total of $113 \mathrm{P}$. damselae subsp. piscicida strains and $20 P$. damselae subsp. damselae strains, isolated from different geographical areas and from the main affected fish species, were analysed using 129 morphological and biochemical tests, including the commercial API 20E and API CH50 test systems. For comparison, the type strains of other Photobacterium species (i.e. Photobacterium leiognathi and Photobacterium angustum) were included in the analyses. The results were statistically analysed by unweighted pair group average clustering and the distance between the different clusters was expressed as the percentage disagreement. The analyses showed that, based on morphological and biochemical identification tests, $P$. damselae subsp. piscicida is related to other Photobacterium species. However, it is clearly distinguishable from $P$. damselae subsp. damselae and no phenotypic evidence was found to include $P$. damselae subsp. piscicida as a subspecies in the species $P$. damselae.
\end{abstract}

Keywords: phenotypic characterization, numerical taxonomy, Photobacterium, Photobacterium damselae subsp. piscicida

\section{INTRODUCTION}

Photobacterium damselae subsp. piscicida is the causative agent of the fish disease pasteurellosis. This disease was first observed in natural populations of white perch (Morone americanus) and striped bass (Morone saxatilis) in 1963 in Chesapeake Bay, USA (Snieszko et al., 1964). In 1969, the pathogen became economically significant with detrimental fish losses in the Japanese fish culture industry (Kusuda \& Yamaoka, 1972). Until recently, Europe was considered to be free of fish pasteurellosis. However, in 1990 several outbreaks of fish pasteurellosis occurred in cultured populations of sea bass (Dicentrarchus labrax) and sea bream (Sparus aurata) in different European countries including France (Baudin Laurencin et al., 1991), Italy (Ceschia e't al., 1991), Spain (Toranzo et al., 1991),

† Present address: Intervet International BV, PO Box 31, NL-5830 AA Boxmeer, The Netherlands.

Abbreviations: TCBS agar, thiosulfate/citrate/bile/sucrose agar; UPGMA, unweighted pair group method with averages.
Greece (Bakopoulos et al., 1995), Portugal (Baptista et al., 1996), Turkey (Candan et al., 1996), and Malta (Bakopoulos et al., 1997). Pasteurellosis continues to be a serious problem in the intensive culture of different fish species in the Mediterranean Sea and Japan.

The taxonomic position of $P$. damselae subsp. piscicida is controversial. Based on morphological and biochemical characterization, the organism was first placed in the genus Pasteurella and given the name 'Pasteurella piscicida' or 'fish killer' (Janssen \& Surgalla, 1968). Although this species is clearly distinguishable from the other species within the genus Pasteurella (i.e. by positive reactions for arginine dihydrolase and the methyl red test, and negative reactions for nitrate reduction and growth at 37 and $42{ }^{\circ} \mathrm{C}$ ), the organism remained in this genus. However, De Ley et al. (1990) reported that, based on analysis of rRNA cistrons, 'Pasteurella piscicida' should be classified in the family Vibrionaceae. This argument was supported by fatty acid methyl ester profiling (Romaldo et al., 1995). More recently, Gauthier et al. (1995) found that, based on rRNA sequence and 
DNA-DNA hybridization data, the pathogen was closely related to $P$. damselae and proposed that it be placed in the genus Photobacterium as a subspecies of $P$. damselae.

In this report, the taxonomic position of the pathogen $P$. damselae subsp. piscicida was clarified by standard and commercial (API 20E and API CH50) morphological and biochemical identification tests.

\section{METHODS}

Bacterial strains and culture conditions. A total of 137 strains was used in this study. Diagnoses were obtained and verified by comparing the reaction profiles of the strains with the description of the species. One-hundred-and-thirteen strains were identified as $P$. damselae subsp. piscicida, 20 as $P$. damselae subsp. damselae, one as Photobacterium angustum, two as Photobacterium leiognathi and one as Photobacterium fischeri. The $P$. damselae subsp. piscicida collection contained isolates from Europe (58), Japan (43) and the USA (two), 36 of which were isolated from sea bass, 22 from sea bream and 34 from yellowtail. These strains were all isolated between 1963 and 1997. The $P$. damselae subsp. damselae collection consisted of one strain isolated from human, one from brown shark, one from oyster, one from seawater, seven from shrimp and six from different fish species. Information concerning the source of the remaining $P$. damselae subsp. damselae strains was not available. The reference and type strains included in this study were: $P$. damselae subsp. piscicida ATCC 17911 and NCIMB 25918 ${ }^{\mathrm{T}}$; $P$. damselae subsp. damselae ATCC 35083, ATCC $33539^{\mathrm{T}}$ and NCIMB $2184^{\mathrm{T}}\left(=\mathrm{ATCC} 33539^{\mathrm{T}}\right) ; P$. leiognathi $\mathrm{LMG}$ $4228^{\mathrm{T}}$; $P$. angustum NCIMB $1895^{\mathrm{T}}$; and $P$. fischeri ATCC 25918 (a complete list of strains may be obtained from the author).

Bacterial cultures were maintained on long-term preservation medium (West \& Colwell, 1984) and reactivated on brain/heart infusion agar (Difco) to which $1 \%(\mathrm{w} / \mathrm{v}) \mathrm{NaCl}$ was added (BN medium) and incubated for $48 \mathrm{~h}$ at $26^{\circ} \mathrm{C}$.

Morphological and biochemical testing of the isolates. All media contained a final $\mathrm{NaCl}$ concentration of $1.5 \%(\mathrm{w} / \mathrm{v})$ and the isolates were incubated for $72 \mathrm{~h}$ at $26^{\circ} \mathrm{C}$ unless noted otherwise. The Gram reaction, nitrate reduction, luminescence, the indole reaction, salt tolerance for growth $(0,0 \cdot 5,3,6,8$ and $10 \%, w / v, N a C l)$, and production of alginase, amylase, deoxyribonuclease, gelatinase and lipase (Tween 80 ) were tested according to the methods described by West \& Colwell (1984). Motility was determined by the hanging drop method. The oxidase reaction was tested on oxidase test disks (bioMérieux) and catalase production was assessed with $3 \%(\mathrm{v} / \mathrm{v}) \mathrm{H}_{2} \mathrm{O}_{2}$. $\beta$-Haemolysis and antibiotic resistance to vibriostatic agent $\mathrm{O} / 129$ (10 and $150 \mu \mathrm{g}$; Oxoid) and novobiocin $(5 \mu \mathrm{g}$; Diagnostics Pasteur) were recorded on tryptic soy agar supplemented with $5 \%(\mathrm{v} / \mathrm{v})$ sheep blood containing $0.5 \%(\mathrm{w} / \mathrm{v}) \mathrm{NaCl}$ (bioMérieux). The bacteria were scored as sensitive for these antibiotics if an inhibition zone could be detected. Temperature tolerance for growth was examined on $\mathrm{BN}$ plates incubated at 4,37 and $42^{\circ} \mathrm{C}$. The methyl red and Voges-Proskauer tests were conducted in MR-VP medium (Difco). Fermentative versus oxidative metabolism of glucose, gas production from glucose (inverted Durham tube), and lysine and ornithine decarboxylase production (Moeller) were analysed as described by Twedt (1978). Arginine dihydrolase was assessed by the method of Thornley (1960). Reaction on Kligler iron agar (Difco), growth and reaction on thiosulfate/citrate/ bile/sucrose (TCBS) agar (Difco) and MacConkey agar (No. 3; Oxoid) were examined. Tartrate utilization was tested on phenol red tartrate agar (Difco). Growth on citrate as the sole source of energy was tested on Simmons citrate agar (Difco). Utilization of malonate, production of phenylalanine deaminase, aesculin hydrolysis, casein hydrolysis and the phosphatase reaction were examined according to the methods described by Smibert \& Krieg (1984). Elastinase production was tested on elastinase agar as described by $\mathrm{Hsu}$ et al. (1981). The Gram reaction, catalase and oxidase activity, and motility were determined after $24 \mathrm{~h}$. Phenylalanine deaminase activity, aesculin hydrolysis, growth on Simmons citrate agar, use of malonate and tartrate, and growth temperature tolerance were examined after $7 \mathrm{~d}$. TCBS and MacConkey media and BN plates, used to test growth temperature tolerance, were inoculated from a McFarland standard No. 3 bacterial suspension in saline $(\mathrm{NaCl} 1.5 \%, \mathrm{w} / \mathrm{v})$. Antibiotic resistance was determined by the disk diffusion method on Mueller-Hinton agar (Difco). The following antimicrobial agents were tested: amoxicillin $(25 \mu \mathrm{g})$, ampicillin $(10 \mu \mathrm{g})$, chloramphenicol $(30 \mu \mathrm{g})$, flumequine $(30 \mu \mathrm{g})$, gentamicin $(10 \mu \mathrm{g})$, kanamycin $(30 \mu \mathrm{g})$, neomycin $(30 \mu \mathrm{g})$, nitrofurantoin $(300 \mu \mathrm{g})$, oxacillin $(1 \mu \mathrm{g})$, penicillin $\mathrm{G}(10 \mu \mathrm{g})$, streptomycin $(10 \mu \mathrm{g})$, tetracycline $(30 \mu \mathrm{g})$, and trimethoprim-sulfamethoxazole $(1.25+23.75 \mu \mathrm{g})$ (bioMérieux). Antibiotic resistance was determined according to the bioMérieux manual.

API 20E and API CH50 (bioMérieux) reactions were carried out as described in the bioMérieux manual and incubated for $72 \mathrm{~h}$. The carbohydrate test tubes were sealed with sterile mineral oil

Numerical taxonomy. The results of the 137 strains (including reference and type strains) examined by the 129 different tests were scored as 1 (positive) and 0 (negative) and incorporated in a larger data matrix (137 strains/129 characters). Unweighted pair group method with averages (UPGMA) clustering (Sneath \& Sokal, 1973) was performed using the cluster analysis program of Statistica for Windows. The distance between the different clusters was expressed in percentage disagreement.

Test reproducibility was evaluated by duplicating tests with two strains; the corresponding error was estimated according to Sneath \& Johnson (1972).

\section{RESULTS}

\section{Numerical taxonomy}

The results of the 137 strains tested against 129 biochemical tests were analysed by UPGMA clustering based on the percentage disagreement. The dendrogram is presented in Fig. 1. Table 1 gives the reaction profiles obtained for each of the clustered and unclustered strains included in this analysis. The probability of test error was $3.6 \%$.

At the level of $13.5 \%$ disagreement, three clusters $(1,2$ and 3 ) and one unclustered strain could be distinguished. The clusters differed in terms of arginine dihydrolase and lysine decarboxylase activity, motility, $\beta$-haemolysis, growth in $0.5 \% \mathrm{NaCl}$, Voges-Proskauer test, growth at $37^{\circ} \mathrm{C}$, nitrate reduction, Kligler test, growth on TCBS and MacConkey media, production of amylase and phosphatase, antibiotic resistance 


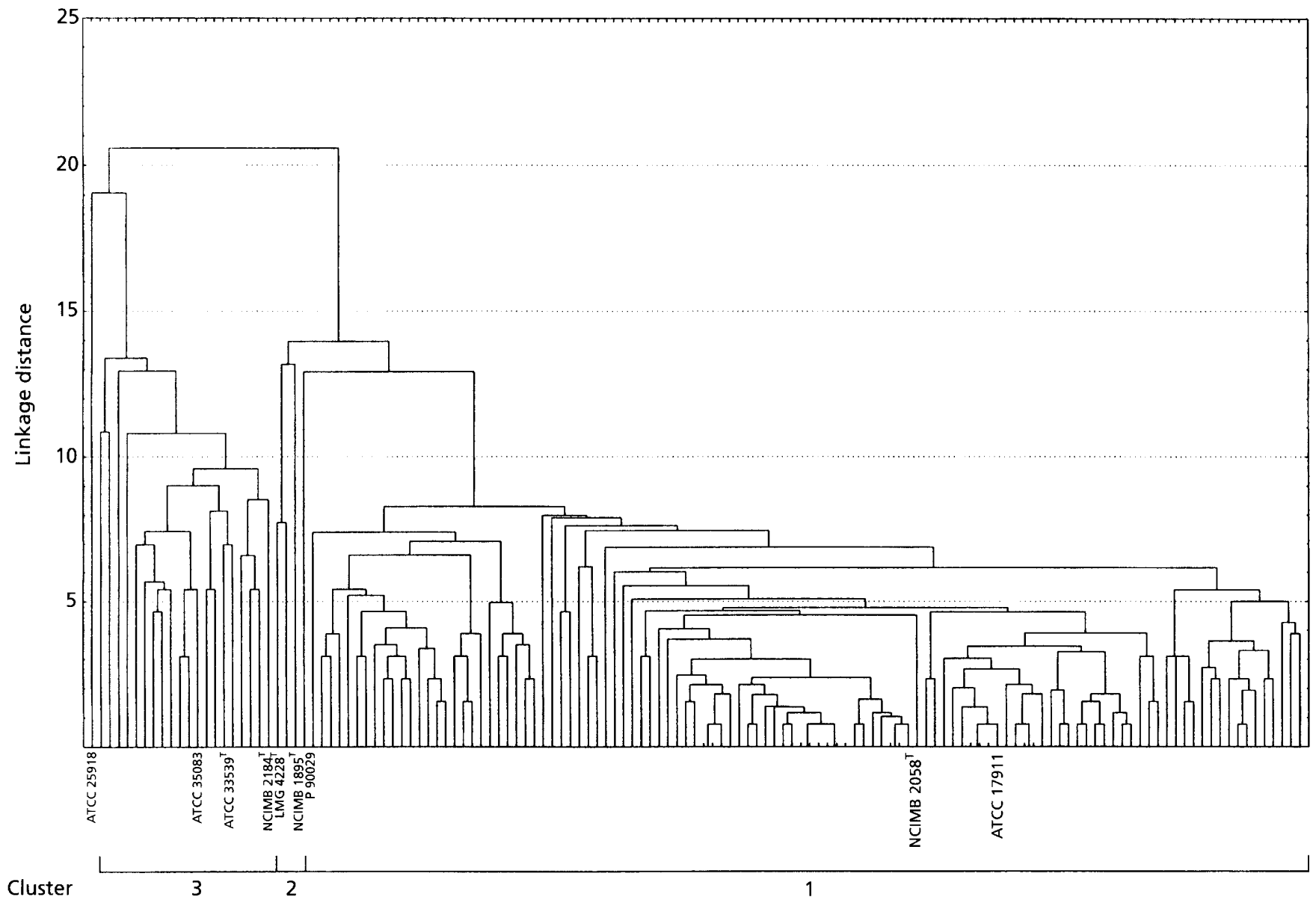

Fig. 1. Dendrogram based on UPGMA clustering using the percentage disagreement.

(penicillin $\mathrm{G}$, ampicillin, kanamycin and amoxicillin), utilization of tartrate, and fermentation of glycerol, salicin, cellobiose, maltose, trehalose and amidon.

Cluster 1 formed at $13 \%$ disagreement and contained the majority of all strains tested ( 113 strains or $82.5 \%$ ). The reference and type strains of $P$. damselae subsp. piscicida (ATCC 17911 and NCIMB 2058 ${ }^{\mathrm{T}}$, respectively) were located in this cluster. All but one of the strains clustered at a much lower degree of dissimilarity $(7 \%)$. The aberrant strain, P 90029 , which joined the other bacteria from cluster 1 at $13 \%$ disagreement, was isolated in 1990 in Japan from a diseased yellowtail. This bacterium could be clearly distinguished from the other strains by a positive reaction for urease and by the ability to ferment maltose and lactose in the API CH50 gallery. The bacteria from cluster 1 in general were characterized by a negative reaction for nitrate reduction and the inability to produce phosphatase. All bacteria were Simmons citrate-negative, although $18 \%$ of them scored positive for Simmons citrate in the commercial API 20E test system.

Cluster 2 formed at $13.5 \%$ disagreement and consisted of three strains: the type strains of $P$. leiognathi (LMG
$4228^{\mathrm{T}}$ ) and $P$. angustum (NCIMB $1895^{\mathrm{T}}$ ) and one additional $P$. leiognathi strain which was donated by John Lee (Department of Biochemistry, University of Georgia, Athens, GA, USA). Although the two type strains clustered together, they could still be distinguished from one another. $P$. angustum differed from $P$. leiognathi by positive reactions for oxidase, catalase, gelatinase, caseinase, DNase, methyl red, aesculin hydrolysis, and fermentation of saccharose and maltose, and negative reactions for nitrate reduction, growth at $37^{\circ} \mathrm{C}$, luminescence, fermentation of glycerol and gluconate, and sensitivity to kanamycin and novobiocin. Cluster 2 joined cluster 1 at $14 \%$ disagreement.

Cluster 3 formed at $13.5 \%$ disagreement and contained 20 strains. The bacteria from cluster 3 produced gas and amylase, were resistant to amoxicillin and fermented glycerol and maltose. Although the two different isolates (ATCC $33539^{\mathrm{T}}$ and NCIMB 2184 of the type strain of $P$. damselae subsp. damselae are both located in this cluster they could be distinguished from one another. In contrast to ATCC $33539^{\mathrm{T}}$, NCIMB $2184^{\mathrm{T}}$ was characterized by positive reactions for methyl red, amylase production, citrate utilization, 
Table 1. Reaction profiles obtained for the different clusters and $P$. fischeri

The numbers in the table refer to the number of strains that give a positive reaction for a given character (percentages are given in parentheses); +, all strains positive; -, all strains negative. All strains showed negative reactions for Gram-staining, ornithine decarboxylase, $\mathrm{H}_{2} \mathrm{~S}$ production, TDA, indole production (standard test, not commercial test), growth in 0,8 and $10 \% \mathrm{NaCl}$, growth at $4{ }^{\circ} \mathrm{C}$, malonate utilization, and fermentation of mannose, inositol, sorbitol, rhamnose, melibiose, D-arabinose, L-arabinose, erythritol, D-xylose, L-xylose, adonitol, methyl $\beta$ xyloside, L-sorbose, dulcitol, mannitol, methyl $\alpha$-D-mannoside, amygdalin, inulin, melezitose, Draffinose, xylitol, D-lyxose, D-tagatose, D-fucose, D-arabitol, L-arabitol, $\beta$-gentiobiose, 2 ketogluconate and 5-ketogluconate. All strains were positive for oxidative and fermentative reactions, growth in $3 \% \mathrm{NaCl}$ and fermentation of D-glucose, D-fructose and D-mannose.

\begin{tabular}{|c|c|c|c|c|}
\hline & Cluster 1 & Cluster 2 & Cluster 3 & P. fischeri \\
\hline No. of strains in each cluster & 113 & 3 & 20 & 1 \\
\hline $\begin{array}{l}\text { API 20E } \\
\beta \text {-Galactosidase }\end{array}$ & - & - & $1(5)$ & - \\
\hline $\begin{array}{l}\beta \text {-Galactosidase } \\
\text { Arginine dihydrolase }\end{array}$ & $108(96)$ & + & $19(95)$ & - \\
\hline Lysine decarboxylase & - & - & $11(55)$ & + \\
\hline Citrate utilization & $20(18)$ & - & $3(15)$ & - \\
\hline Urease & $1(<1)$ & - & $17(85)$ & - \\
\hline Indole production & - & - & $1(5)$ & - \\
\hline Voges-Proskauer test & $109(96)$ & + & + & + \\
\hline Gelatinase & - & $1(33)$ & $4(20)$ & - \\
\hline \multicolumn{5}{|l|}{ Fermentation of: } \\
\hline Glucose & $110(97)$ & + & + & + \\
\hline Saccharose & - & $1(33)$ & $1(5)$ & - \\
\hline Amygdalin & - & - & $3(15)$ & + \\
\hline Oxidase activity & $103(91)$ & $2(67)$ & $15(75)$ & + \\
\hline Catalase activity & $105(93)$ & $2(67)$ & $19(95)$ & + \\
\hline Motility & - & - & $19(95)$ & + \\
\hline$\beta$-Haemolysis & - & - & $17(85)$ & - \\
\hline \multicolumn{5}{|l|}{ Sensitivity to: } \\
\hline $\mathrm{O} / 129(10 \mu \mathrm{g})$ & $75(66)$ & + & $14(70)$ & - \\
\hline $\mathrm{O} / 129(150 \mu \mathrm{g})$ & $93(82)$ & + & + & + \\
\hline Novobiocin $(5 \mu \mathrm{g})$ & $93(82)$ & $2(67)$ & $18(90)$ & + \\
\hline \multicolumn{5}{|l|}{ Growth at: } \\
\hline $0.5 \% \mathrm{NaCl}$ & $97(86)$ & + & $19(95)$ & - \\
\hline $6 \% \mathrm{NaCl}$ & $3(3)$ & + & $18(90)$ & + \\
\hline $37{ }^{\circ} \mathrm{C}$ & $61(54)$ & $1(33)$ & $19(95)$ & - \\
\hline $42{ }^{\circ} \mathrm{C}$ & $1(<1)$ & - & $11(55)$ & - \\
\hline Voges-Proskauer test & $110(97)$ & + & $15(75)$ & - \\
\hline Methyl red reaction & $110(97)$ & $2(67)$ & $19(95)$ & - \\
\hline Arginine dihydrolase & $108(96)$ & + & $19(95)$ & - \\
\hline Lysine decarboxylase & - & $1(33)$ & $5(25)$ & + \\
\hline Nitrate reduction & - & $1(33)$ & $17(85)$ & + \\
\hline Simmons citrate reaction & - & - & $4(20)$ & - \\
\hline Tartrate & $2(2)$ & $1(33)$ & $4(20)$ & + \\
\hline TCBS growth & - & $1(33)$ & $19(95)$ & - \\
\hline TCBS sucrose & - & - & $1(5)$ & - \\
\hline \multicolumn{5}{|l|}{ Kligler test: } \\
\hline Glucose & $81(72)$ & + & $18(90)$ & - \\
\hline Lactose & $85(75)$ & + & $16(80)$ & - \\
\hline Gas & - & - & $9(45)$ & - \\
\hline MacConkey growth & $52(46)$ & $2(67)$ & $19(95)$ & - \\
\hline Lipase production & $108(96)$ & $2(67)$ & $15(75)$ & + \\
\hline Amylase production & $60(53)$ & - & + & - \\
\hline Gelatinase production & - & $1(33)$ & $3(15)$ & - \\
\hline DNase production & $83(73)$ & $1(33)$ & + & + \\
\hline
\end{tabular}


Table 1. (cont.)

\begin{tabular}{|c|c|c|c|c|}
\hline & Cluster 1 & Cluster 2 & Cluster 3 & P. fischer \\
\hline Phenylalanine deaminase & - & - & $1(5)$ & - \\
\hline Caseinase production & $1(<1)$ & $1(33)$ & - & - \\
\hline Phosphatase production & $1(<1)$ & + & + & + \\
\hline Aesculin hydrolysis & - & $1(33)$ & $6(30)$ & - \\
\hline Luminescence & - & $2(67)$ & - & - \\
\hline Gas production & - & - & $13(65)$ & - \\
\hline \multicolumn{5}{|l|}{ Sensitivity to: } \\
\hline Flumequine & $110(97)$ & + & $18(90)$ & + \\
\hline Tetracycline & $88(78)$ & + & $17(85)$ & + \\
\hline Gentamicin & $111(98)$ & + & $17(85)$ & + \\
\hline Neomycin & $83(73)$ & + & $11(55)$ & + \\
\hline Chloramphenicol & $84(74)$ & + & $19(95)$ & + \\
\hline Penicillin G & $103(91)$ & - & - & - \\
\hline Flumiquine & $112(99)$ & + & + & + \\
\hline Oxacillin & $2(2)$ & - & - & - \\
\hline Ampicillin & $107(95)$ & + & $1(5)$ & - \\
\hline Streptomycin & $64(57)$ & - & $1(5)$ & - \\
\hline Trimethoprim-sulfamethoxazole & $112(99)$ & + & $18(90)$ & + \\
\hline Kanamycin & $81(72)$ & $2(67)$ & $9(45)$ & - \\
\hline Amoxicillin & $108(96)$ & - & - & - \\
\hline \multicolumn{5}{|l|}{ API CH50 } \\
\hline \multicolumn{5}{|l|}{ Fermentation of: } \\
\hline Glycerol & $1(<1)$ & $2(67)$ & + & - \\
\hline Ribose & $96(85)$ & + & + & + \\
\hline Galactose & $105(93)$ & + & + & + \\
\hline Methyl $\alpha$-D-glucoside & - & - & $2(10)$ & - \\
\hline$N$-Acetylglucosamine & $111(98)$ & + & + & + \\
\hline Arbutin & - & - & $2(10)$ & - \\
\hline Aesculin & - & - & $2(10)$ & - \\
\hline Salicin & $1(<1)$ & - & $3(15)$ & + \\
\hline Cellobiose & - & - & $17(85)$ & + \\
\hline Maltose & $2(2)$ & $1(67)$ & + & + \\
\hline Lactose & $1(<1)$ & - & - & - \\
\hline Saccharose & $2(2)$ & - & $2(10)$ & - \\
\hline Trehalose & - & - & $16(80)$ & - \\
\hline Amidon & - & - & $16(80)$ & + \\
\hline Glycogen & - & - & $6(30)$ & - \\
\hline D-Turanose & $1(<1)$ & - & $3(15)$ & - \\
\hline Gluconate & - & $2(67)$ & - & - \\
\hline
\end{tabular}

sensitivity to trimethoprim-sulfamethoxazole, and negative reactions for oxidase, urease, VogesProskauer test, aesculin hydrolysis, gas production, and sensitivity to gentamicin, neomycin and kanamycin. Cluster 3 joined clusters 1 and 2 at $20.5 \%$ disagreement.

The unclustered strain, $P$. fischeri ATCC 25918, joined cluster 3 at $19 \%$ disagreement and was characterized by a negative reaction on the Kligler test, sensitivity to $\mathrm{O} / 129(10 \mu \mathrm{g})$, production of lysine decarboxylase and growth in $6 \% \mathrm{NaCl}$. It should be noted that the bacterium scored positive for the Voges-Proskauer test in commercial medium, but negative in MR-VP medium.

\section{DISCUSSION}

The probability of test error was calculated as $3.6 \%$, which is an acceptable value according to the criteria of Sneath \& Johnson (1972). This means that the different reaction profiles for the two isolates of the type strain $P$. damselae subsp. damselae, ATCC $33539^{\mathrm{T}}$ and NCIMB $2184^{\mathrm{T}}$, are probably not due to a lack of test reproducibility. It is known, however, that maintenance of a strain within a laboratory by repeated subculture can result in a decrease in its vigour and the loss or change of some characteristics (Bryant et al., 1986).

The reaction profiles of some of the bacteria were not 
completely in agreement with the general profile of the species to which they belonged for a number of tests, e.g. oxidase and catalase activity, production of lipase, growth in $0.5 \% \mathrm{NaCl}$, and methyl red and VogesProskauer tests. A number of strains had a weak positive reaction for these tests. In the analysis of results, these reactions were scored as negative.

The reaction profiles of the 113 strains of cluster 1 are basically in agreement with the amended description of $P$. damselae subsp. piscicida made by Gauthier et al. (1995). The bacteria only differed by negative reactions for the fermentation of mannose, saccharose and raffinose. These aberrant reactions can be explained by the different reaction conditions used for the API CH50 gallery. In contrast to Gauthier et al. (1995), a $1.5 \%$ saline suspension was used as inoculum in this study. Moreover, the incubation temperature and time were increased to $26^{\circ} \mathrm{C}$ and $72 \mathrm{~h}$, respectively. Phenotypic characterization showed that $P$. damselae subsp. piscicida is a Gram-negative, non-motile coccobacillus with bipolar staining. The bacterium is characterized by positive reactions for arginine dihydrolase, methyl red and Voges-Proskauer tests, production of oxidase and fermentation of ribose, and negative reactions for nitrate reduction, indole production, production of alginase and gelatinase, growth at $42^{\circ} \mathrm{C}$ and fermentation of saccharose. A full description of $P$. damselae subsp. piscicida is given in Table 1. Strain $\mathbf{P}$ 90029 differed from the other cluster 1 bacteria by aberrant reactions on the API 20E and API CH50 galleries (see Results). Due to the negative reactions for arginine dihydrolase and fermentation of glucose and the positive reaction for urease production, $\mathrm{P}$ 90029 exhibited an API 20E index profile of 0011004. Based on positive reactions for arginine dihydrolase, Voges-Proskauer test and fermentation of glucose, $P$. damselae subsp. piscicida generally displays a unique code of 2005004 (Toranzo et al., 1991). In this analysis, only $76 \%$ (86 out of 113) strains exhibited this index profile. Aberrant reactions for arginine dihydrolase, citrate utilization and Voges-Proskauer test have already been observed by Kent et al. (1982), Hawke et al. (1987) and Candan et al. (1996). Based on these findings, it is concluded that the API 20E test system is not always a useful tool for the identification of $P$. damselae subsp. piscicida. It is suggested that in addition to API 20E, 'classical' tests such as salt tolerance for growth $(0,0 \cdot 5,3,6,8$ and $10 \% \mathrm{NaCl})$, growth temperature tolerance $\left(4,37\right.$ and $\left.42^{\circ} \mathrm{C}\right)$, arginine dihydrolase according to Thornley (1960), classical methyl red and Voges-Proskauer tests, and nitrate reduction, gas production from glucose, and plate tests for the hydrolysis of alginate, casein, elastin, gelatin, starch and DNA should be performed. Based on results of the classical tests, the reaction profile of $\mathrm{P}$ 90029 is in agreement with that of $P$. damselae subsp. piscicida.

Cluster 3 represents the subspecies $P$. damselae subsp. damselae. The reaction profile of this subspecies is in agreement with the description of Gauthier et al. (1995) with the exception of aesculin hydrolysis.

Based on phenotypic characterization, cluster analysis grouped $P$. damselae subsp. piscicida (formerly 'Pasteurella piscicida') together with the Photobacterium species at a level of $19 \%$ disagreement or $81 \%$ agreement. Furthermore, analysis showed that the bacterium is more related to $P$. angustum and $P$. leiognathi than to $P$. damselae subsp. damselae. This result is not in agreement with the genotypic analyses of Gauthier et al. (1995), which showed that 'Pasteurella piscicida' and P. damselae were closely related. Both bacteria shared the same 16S rRNA sequence and exhibited $80 \%$ DNA-DNA hybridization. Based on these findings, 'Pasteurella piscicida' was classified as a subspecies of $P$. damselae and renamed $P$.damselae subsp. piscicida. The present study, on the other hand, found no morphological and/or biochemical evidence to include 'Pasteurella piscicida' as a subspecies of $P$. damselae. As shown in Table 1, the species could be clearly distinguished from $P$. damselae subsp. damselae by negative reactions for motility, nitrate reduction, growth at 37 and $42{ }^{\circ} \mathrm{C}$, growth on TCBS and MacConkey media, $\beta$-haemolysis, production of urease and amylase, and the inability to ferment amidon, cellobiose, maltose and trehalose.

In conclusion, based on the present phenotypic analysis, the species 'Pasteurella piscicida' should be placed along with the other Photobacterium strains in the genus Photobacterium according to positive reactions for arginine dihydrolase and methyl red, and fermentation of ribose, and negative reactions for nitrate reduction, production of alginase and fermentation of sucrose. Because results obtained by phenotypic analyses were not in accordance with those of the genotypic analyses performed by Gauthier et al. (1995), further studies involving ribotyping, random amplification of polymorphic DNA and pulsed-field gel electrophoresis are underway to unravel the taxonomic position of this marine pathogen.

\section{ACKNOWLEDGEMENTS}

We are grateful to T. Aoki, M. Sakai, Y. Fukuda, H. Nousias, K. Satoh, V. Lopez-Doriga, A. Colorni, A. Fabris, J. Lee, N. Y asunaga and T. S. Jung for providing the strains. This work was supported by a personal IWT grant and a FKFO project G.0063.96.

\section{REFERENCES}

Bakopoulos, V., Adams, A. \& Richards, R. H. (1995). Some biochemical properties and antibiotic sensitivities of Pasteurella piscicida isolated in Greece and comparison with strains from Japan, France and Italy. J Fish Dis 18, 1-7.

Bakopoulos, V., Peric, Z., Rodger, H., Adams, A. \& Richards, R. H. (1997). First report of fish pasteurellosis from Malta. $J$ Aquat Anim Health 9, 26-33.

Baptista, T., Romalde, J. L. \& Toranzo, A. E. (1996). First occurrence of pasteurellosis in Portugal affecting cultured gilthead seabream (Sparus aurata). Bull Eur Assoc Fish Pathol 16, 92-95. 
Baudin Laurencin, F., Pepin, J. F. \& Raymond, J. C. (1991). First observation of an epizootic of pasteurellosis in farmed and wild fish of the French Mediterranean coasts. In Abstracts of the Fifth International Conference of the European Association of Fish Pathology, p. 17.

Bryant, T. N., Lee, J. V., West, P.A. \& Colwell, R. R. (1986). Numerical classification of species of Vibrio and related genera. $J$ Appl Bacteriol 61, 437-467.

Candan, A., Kucuker, M. A. \& Karatas, S. (1996). Pasteurellosis in cultured sea bass (Dicentrarchus labrax) in Turkey. Bull Eur Assoc Fish Pathol 16, 150-153.

Ceschia, G., Quaglio, F., Giorgetti, G., Bertoja, G. \& Bovo, G. (1991). Serious outbreak of pasteurellosis (Pasteurella piscicida) in euryhaliene species along the Italian coasts. In Abstracts of the Fifth International Conference of the European Association of Fish Pathology, p. 26.

De Ley, J., Mannheim, W., Mutters, R., Tytgat, K., Segers, P., Bisgaard, M., Frederiksen, W., Hinz, K. H. \& Vanhoucke, M. (1990). Inter- and intrafamilial similarities of rRNA cistrons of the Pasteurellaceae. Int J Syst Bacteriol 40, 126-137.

Gauthier, G., Lafay, B., Ruimy, R., Breittmayer, V., Nicolas, J. L., Gauthier, M. \& Christen, R. (1995). Small-subunit rRNA sequences and whole DNA relatedness concur for the reassignment of Pasteurella piscicida (Sniezko et al.) Janssen and Surgalla to the genus Photobacterium as Photobacterium damselae subsp. piscicida comb. nov. Int J Syst Bacteriol 45, 139-144.

Hawke, J. P., Plakas, S. M., Minton, R. V., McPhearson, R. M., Snider, T. G. \& Guarino, A. M. (1987). Fish pasteurellosis of cultured striped bass (Morone saxatilis) in coastal Alabama. Aquaculture 65, 193-204.

Hsu, T. C., Waltman, W. D. \& Shotts, E. B. (1981). Correlation of extracellular enzymatic activity and biochemical characteristics with regard to virulence of Aeromonas hydrophila. Dev Biol Stand 49, 101-111.

Janssen, W. A. \& Surgalla, M. J. (1968). Morphology, physiology, and serology of a Pasteurella species pathogenic for white perch (Roccus americanus). J Bacteriol 96, 1606-1610.

Kent, M. L. (1982). Characteristics and identification of
Pasteurella and Vibrio species pathogenic to fishes using API20E (Analytab Products) multitube test strips. Can J Aquat Sci 39, 1725-1729.

Kusuda, R. \& Yamaoka, M. (1972). Etiological studies on bacterial pseudotuberculosis in cultured yellowtail with Pasteurella piscicida as the causative agent. I. On the morphological and biochemical properties. Bull Jpn Soc Sci Fish 38, 1325-1332.

Romaldo, J. L., Magariños, B., Turnbull, K. D., Baya, A. N., Barja, J. M. \& Toranzo, A. E. (1995). Fatty acid profiles of 'Pasteurella' piscicida: comparison with other fish pathogenic gram-negative bacteria. Arch Microbiol 163, 211-216.

Smibert, R. M. \& Krieg, N. R. (1984). General characterization. In Manual of Methods for General Microbiology, pp. 409-443. Washington, DC: American Society for Microbiology.

Sneath, P. H. A. \& Johnson, R. (1972). The influence on numerical taxonomic similarities of errors in microbiological tests. $J$ Gen Microbiol 72, 377-392.

Sneath, P. H. A. \& Sokal, R. R. (1973). Numerical Taxonomy: the Principles and Practice of Numerical Classification, 2nd edn. San Francisco: W. H. Freeman.

Snieszko, S. F., Bullock, G. L., Hollis, E. \& Boone, J. G. (1964). Pasteurella sp. from an epizootic of white perch (Roccus americanus) in Chesapeake Bay tidewater areas. $J$ Bacteriol $\mathbf{8 8 ,}$ 1814-1815.

Toranzo, A. E., Barreiro, S., Casal, J. F., Figueras, A., Magariños, B. \& Barja, J. (1991). Pasteurellosis in cultured gilthead seabream (Sparus aurata): first report in Spain. Aquaculture 99, 1-15.

Thornley, M. J. (1960). The differentiation of Pseudomonas from other Gram-negative bacteria on the basis of arginine metabolism. J Appl Bacteriol 23, 37-52.

Twedt, R. M. (1978). Isolation and identification of Vibrio parahaemolyticus. In FDA, Bacteriological Analytical Manual, pp. 1-13. Washington, DC: Association of Official Analytical Chemists.

West, P. A. \& Colwell, R. R. (1984). Identification and classification of Vibrionaceae: an overview. In Vibrios in the Environment, pp. 285-263. Edited by R. R. Colwell. New York: Wiley. 
